\title{
Impact of Differences in Time During The Day on No. of Traffic Accidents Depending on Diversity of Drivers' Genders and Ages in Greece
}

\author{
Jameel Al-Karablieh \\ Division of Transportation and Project Management \\ Aristotle University of Thessaloniki \\ Thessaloniki, Greece
}

\author{
Prof. Fotini Kehagia \\ Division of Transportation and Project Management \\ Aristotle University of Thessaloniki \\ Thessaloniki, Greece
}

\begin{abstract}
The research consists of studying the impacts on traffic accidents No. depending on difference in time of accidents and diversity of drivers' gender and ages' categories. Statistical data which required for the study were collected from Hellenic Statistical Authority (ELSTAT) and included No. of traffic accidents in Greece during period (2012-2016). They divided according to drivers' gender and ages' categories, in addition to differences of accidents time through the day per hour. The study evaluated the difference in No. of traffic accidents which resulted by drivers with their different characteristics during four times of the day which comprised of Late-night/dawn (00:00-05:00 am), morning/noon (06:00-11:00), noon/afternoon (12:00-17:00) and evening/night (18:00-23:00). The analysis phase included studying of relationships between the variables, in addition it concluded a model for No. of which is identification No. of traffic accidents in Greece. Analyzing of data resulted that there is association between different No. of traffic accidents which involved the drivers and the variables which included gender and ages' categories of drivers; and variation of time divisions through the day. In addition, the time division of noon/afternoon that includes the peak of traffic at afternoon (12:00-17:00) considered the critical division for road safety because it has the bigger No. of traffic accidents for all groups of drivers comparison to other divisions of time. Whereas, the time division of Late-night/dawn (00:00-05:00 am) has the lowest No. of traffic accidents comparison to other divisions of time. The young male drivers had the bigger No. of accidents in all time divisions of day comparison to female drivers. The study recommended increasing the traffic awareness among drivers and ensuring to comply with traffic rules while driving the vehicle at all times during the day.
\end{abstract}

Keywords - Traffic accidents, Drivers' characteristics, Driver Gender, Driver Age, Driving at daytime and nighttime, Time of traffic accident, Driver behaviour, Driving in Greece.

\section{INTRODUCTION}

Road accident is one of the most important causes of death and series injuries among healthy people in the world. Every year the lives of more than 1.25 million people are cut short as a result of a road traffic crash. Between 20 and 50 million, more people suffer non-fatal injuries, with many incurring a disability because of their injury. Road traffic injuries cause considerable economic losses to individuals, their families, and to nations as a whole. These losses arise from the cost of treatment as well as lost productivity for those killed or disabled by their injuries, and for family members who need to take time off work or school to care for the injured. Road traffic crashes cost most countries $3 \%$ of their gross domestic product [1].

Nighttime driving is associated with a higher risk of accident involvement due to factors such as reduced visibility, fatigue, and higher incidence of alcohol use. In general, the difference between daytime and nighttime fatal rates was more pronounced among the younger age groups than the older ones. The highest nighttime rates were for the youngest drivers, while the highest daytime rates were for drivers 75 and over. Both males and females experienced higher fatal involvements rates at night than during the day. Men had a higher risk of fatal involvement than women during the day and at night, their night time risk was more pronounced. The oldest group of drivers experienced had the highest daytime fatal rates among both men and women. The injuries rate during the day were female drivers had a higher rate than male drivers, but this was reversed at night time. The difference in the fatal rate between men and women was most extreme among the younger age groups, and by age 60 , the rates for men and women were essentially identical [2].

Driving safety is affected by various factors, which together determine the level of traffic safety or risk such factors include driver characteristics. However, most road accidents are attributed to 'human factor' most especially to road safety violations [3]. Gender has been considered in relation to risky driving behavior in young drivers [4].

Maximum number of accidents occurred during daytime between 6 am and 5:59 pm. [5]. In general, it has been found that, in terms of risk behavior in road traffic, males are more willing to take risks than female [6].

Introducing road lighting leads to an approximate three times decrease in the severity of injuries in both UK and Greece, despite the fact that these countries have dramatically different injury rates. [7]

Fatal crashes caused by female drivers also differ from those caused by male drivers in a range of factors, some of these reflecting different travel. One of the dominant characteristics, however, is the relatively small percentage of fatal crashes caused by women which are attributable to risk taking behaviour [8]. Motor vehicle crash fatalities were higher for males than females in all age groups [9]. 
Young drivers experienced higher relative risks of single vehicle crashes than did older drivers of the same sex. Additionally, female drivers exhibited substantially lower relative risk than male drivers of the same age [10].

In Greece, data Crash in 2015 stagnated at the 2014 level, following five consecutive years with a significant (generally above $10 \%$ ) decrease in fatalities, resulting in an overall decrease for the period $2009-14$ of $45 \%$. The fatality rate for Greece (7.3 deaths per 100000 inhabitants) is for the second year closer to the EU average than to the least performing EU countries. However, while the economic downturn is not yet over, Greece has probably reached the point at which the drop in road fatalities has levelled off [11].

Young drivers have the great majority of their accidents by losing control on bends or curves, typically at night in rural areas and/or while driving for 'leisure' purposes. Older drivers had fewer accidents, but those fatalities they were involved in tended to involve misjudgment and perceptual errors in 'right of way' collisions, typically in the daytime on rural rather than urban roads. Blameworthy right of way errors were notably high for drivers aged over 65 years, as a proportion of total fatal accidents in that age group. It can be seen that drivers aged 20 years or under appeared to be nearly 12 times more likely to have caused a fatal accident than they were to have been innocently involved in such an accident. This effect decreased dramatically with increasing driver age, only rising again beyond the age of 65 ; results in the last age group should be treated with caution as there are only a small number of drivers in the sample aged 8690 years. [12]

The research evaluated whether there are effects and association between the different characteristics of drivers in terms of genders and ages' categories with variation of time occurrence of accidents through the day on different No. of traffic accidents by depending on the statistical data which collected from ELSTAT during period (2012-2016). In addition, the study explained the most and the less affected of variety groups of drivers in different divisions of time during the day that include peak times of traffic by the assessment No. of traffic accidents which resulted. The results which got by data analysis will answer the hypotheses that proposed in the research.

\section{HYPOTHESES OF STUDY}

The main hypotheses that are inclusive in the study as following:

1. There are not association between total No. of traffic accidents which involved the drivers and the variation of time divisions through the day during different years.

2. There are not association between total No. of traffic accidents and the gender of drivers who involved in these accidents through different of time divisions during the day.

3. There are not association between total No. of traffic accidents and ages of drivers who involved in these accidents through different time divisions of day.

4. There are not association between the variables of gender, ages' categories of drivers and variation of time divisions through day for impaction on differences No. of traffic accidents during period of study.

\section{METHODOLOGY OF STUDY}

The main steps which are included in the study as the following:

1. Obtaining the required statistical data from ELSTAT for No. of traffic accidents during period (2012-2016) divided according to time occurrence of traffic accidents.

2. Arranging of statistical data in suitable forms for analyzing which comprised of four divisions of time through the day.

3. Analyzing of data depending on appropriate statistical tests for each part by using SPSS software and preparing model which predict No. of traffic accidents.

4. Illustration the results which got by data analyzing and discussion of them.

5. Showing the conclusions consideration to the results that got by the study.

6. Recommendations depending on the results and conclusions.

\section{Data Collection}

The study relied on authorized source for statistical data of traffic accidents that obtained from ELSTAT. The statistical data included No. of traffic accidents at the time of accidents occurrence per hour and classified to age and gender groups of drivers for five years and during the period (2012-2016) as shown in Table 1. The data arranged in suitable forms for analyzing and dividing to four divisions of time. In addition, there are very few missing of traffic accidents information depending on details in tables of data that received from ELSTAT and these missed information are not effecting on the analyzing process.

\section{Analysis of Data}

The phase of data analyzing comprised of diversity of statistical tests for each kind of data by used of SPSS software. They included Chi-square test and Univariate test; In addition, the study created a model which predicted No. of traffic accidents in Greece. In analysis of data; the study divided time of day to four divisions; Late-night/dawn (00:00-05:00 am), morning/noon that include peak morning (06:00-11:00), noon/afternoon that include peak afternoon (12:00-17:00), and evening/night (18:00-23:00). The research based on two types of variables; dependent variables that included traffic accidents No. and independent variables that contained of occurrence times of traffic accidents, gender and ages categories of drivers who involved in the accidents. This stage studied the influences of different variables on different No. of traffic accidents. Also, interpretation of the association between the variables. There are four parts of data analysis as the following:

1. Examine the influence of time variance of traffic accidents through day on differences of accidents No. that involved of drivers during period $(2012-2016)$ :

\section{- Description Analysis:}

The data that collected from ELSTAT are contained of traffic accidents No. that depending on times of accidents occurrence. The descriptive analysis is illustration that there are differences 
Table 1: Statistical Data of No. of Traffic Accidents per Hour during period (2012-2016)

\begin{tabular}{|c|c|c|c|c|c|}
\hline \multirow{2}{*}{$\begin{array}{c}\text { Hour of } \\
\text { Traffic } \\
\text { Accident }\end{array}$} & \multicolumn{5}{|c|}{ No. of Traffic Accidents } \\
\hline & 2012 & 2013 & 2014 & 2015 & 2016 \\
\hline 0 & 316 & 268 & 261 & 200 & 204 \\
\hline 1 & 237 & 239 & 200 & 235 & 211 \\
\hline 2 & 207 & 145 & 184 & 181 & 178 \\
\hline 3 & 229 & 186 & 170 & 160 & 153 \\
\hline 4 & 208 & 173 & 193 & 163 & 164 \\
\hline 5 & 243 & 222 & 197 & 179 & 157 \\
\hline 6 & 280 & 246 & 252 & 256 & 237 \\
\hline 7 & 339 & 332 & 318 & 310 & 291 \\
\hline 8 & 502 & 518 & 474 & 473 & 471 \\
\hline 9 & 549 & 523 & 534 & 490 & 453 \\
\hline 10 & 668 & 634 & 625 & 556 & 594 \\
\hline 11 & 728 & 731 & 661 & 664 & 657 \\
\hline 12 & 760 & 816 & 736 & 712 & 675 \\
\hline 13 & 858 & 800 & 737 & 782 & 756 \\
\hline 14 & 794 & 851 & 803 & 778 & 767 \\
\hline 15 & 690 & 703 & 682 & 750 & 710 \\
\hline 16 & 670 & 617 & 628 & 678 & 620 \\
\hline 17 & 639 & 628 & 654 & 575 & 597 \\
\hline 18 & 706 & 738 & 680 & 629 & 674 \\
\hline 19 & 668 & 625 & 708 & 602 & 610 \\
\hline 20 & 639 & 564 & 613 & 576 & 558 \\
\hline 21 & 589 & 581 & 531 & 555 & 500 \\
\hline 22 & 479 & 525 & 479 & 467 & 456 \\
\hline 23 & 400 & 392 & 349 & 423 & 378 \\
\hline Total & 12,398 & 12,057 & 11,669 & 11,394 & 11,071 \\
\hline
\end{tabular}

in total No. of traffic accidents according to times of accidents through period of study (2012-2016) as shown in the statistical Table 2 and Figure 1. The study indicated that some divisions of time have more traffic accidents comparison to another times during the day.

Table 2: Statistical Data of Total No. of Traffic Accidents According to Variation of Time Divisions of Day

\begin{tabular}{|c|c|c|c|c|c|}
\hline \multirow{2}{*}{$\begin{array}{c}\text { Time Division of } \\
\text { Day }\end{array}$} & \multicolumn{5}{|c|}{ Year } \\
\cline { 2 - 6 } & $\mathbf{2 0 1 2}$ & $\mathbf{2 0 1 3}$ & $\mathbf{2 0 1 4}$ & $\mathbf{2 0 1 5}$ & $\mathbf{2 0 1 6}$ \\
\hline $\begin{array}{c}\text { Late night/Dawn } \\
(00: 00-05: 00)\end{array}$ & 1440 & 1233 & 1205 & 1118 & 1067 \\
\hline $\begin{array}{c}\text { Morning/Noon } \\
(06: 00-11: 00)\end{array}$ & 3066 & 2984 & 2864 & 2749 & 2703 \\
\hline $\begin{array}{c}\text { Noon/Afternoon } \\
(12: 00-17: 00)\end{array}$ & 4411 & 4415 & 4240 & 4275 & 4125 \\
\hline $\begin{array}{c}\text { Evening/Night } \\
(18: 00-23: 00)\end{array}$ & 3481 & 3425 & 3360 & 3252 & 3176 \\
\hline Total & $\mathbf{1 2 3 9 8}$ & $\mathbf{1 2 0 5 7}$ & $\mathbf{1 1 6 6 9}$ & $\mathbf{1 1 3 9 4}$ & $\mathbf{1 1 0 7 1}$ \\
\hline
\end{tabular}

Table 3: Descriptive for Data Analysis

\begin{tabular}{|c|c|c|c|c|}
\hline $\begin{array}{c}\text { Time Division of } \\
\text { Day }\end{array}$ & $\begin{array}{c}\text { No. of } \\
\text { Traffic } \\
\text { Accidents } \\
\end{array}$ & Mean & $\begin{array}{c}\text { Std. } \\
\text { Deviation }\end{array}$ & $\begin{array}{l}\text { Std. Error } \\
\text { of Mean }\end{array}$ \\
\hline $\begin{array}{l}\text { Late night/Dawn } \\
(00: 00-05: 00)\end{array}$ & 6063 & 63.64 & 42.195 & 0.542 \\
\hline $\begin{array}{l}\text { Morning/Noon } \\
(06: 00-11: 00)\end{array}$ & 14366 & 90.54 & 44.153 & 0.368 \\
\hline $\begin{array}{c}\text { Noon/Afternoon } \\
(12: 00-17: 00)\end{array}$ & 21466 & 121.61 & 58.197 & 0.397 \\
\hline $\begin{array}{l}\text { Evening/Night } \\
(18: 00-23: 00) \\
\end{array}$ & 16694 & 110.06 & 62.090 & 0.481 \\
\hline Total & 58589 & 104.70 & 57.776 & 0.239 \\
\hline
\end{tabular}

Late night/Dawn (00:00 - 05:00) - Morning/Noon (06:00 - 11:00) Noon/Afternoon (12:00-17:00) Evening/Night (18:00-23:00)

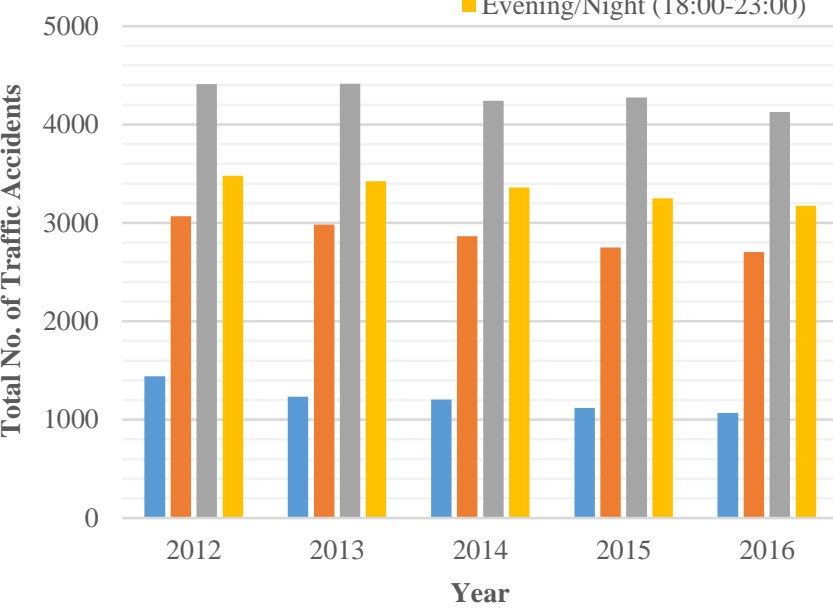

Figure 1: Indication of Total No. of Traffic Accidents through Different Time Divisions of Day during period (2012-2016)

Depending on the values which shown in Table 2 and Figure 1; we observed that year of 2012 had the bigger No. of accidents in all time divisions of day and the values decreased from years 2012 to 2016. In addition, the time division of noon/afternoon that include peak afternoon (12:00-17:00) has the bigger No. of accidents in each year during the period. After that the time divisions of evening/night (18:00-23:00), morning/noon (06:0011:00) and Late-night/dawn (00:00-05:00 am) consecutively. Also, as shown in Table 3 the values of mean and standard deviation are arranged gradually according to distribution of accidents No. for each division of time.

In addition, this branch of analysis included testing the significance of differences between total No. of traffic accidents and time divisions of day during years of study. In addition, it shown if the traffic accidents affected through different years by diversity of time divisions depending on data that collected during the period $(2012-2016)$. The hypothesis that assumed as the following: 
$\mathrm{H}_{0}=$ There is not association between total No. of traffic accidents which involved the drivers and the variation of time divisions through the day during different years.

$\mathrm{H}_{1}=$ There is association between total No. of traffic accidents which involved the drivers and the variation of time divisions through the day during different years.

For interpretation of the relationship between the dependent variables which included total No. of traffic accidents and independent variables time divisions of day during different years used "Chi-square test" for testing the significance.

Table 4: Chi-Square Test

\begin{tabular}{|c|c|c|c|}
\hline & Value & df & $\begin{array}{c}\text { Asymp. Sig. } \\
\text { (2-sided) }\end{array}$ \\
\hline Pearson Chi-Square & $38.202^{\mathrm{a}}$ & 12 & 0.000 \\
\hline Likelihood Ratio & 37.664 & 12 & 0.000 \\
\hline $\begin{array}{c}\text { Linear-by-Linear } \\
\text { Association }\end{array}$ & 16.865 & 1 & 0.000 \\
\hline N of Valid Cases & 58589 & & \\
\hline
\end{tabular}

Depending on values of the results in Table 4; the calculated value of chi-square for degree of freedom equals $((\chi 2,12)=$ $38.202)$ and the value of significance $(p=0.000<0.05)$. So that, we reject the hypothesis $\left(\mathrm{H}_{0}\right)$ and accept the hypothesis $\left(\mathrm{H}_{1}\right)$. Then, the differences of total No. of traffic accidents are significant according to diversity of time divisions through the day at level $(p \leq 0.05)$.

2. Assessment the association between the gender of drivers and time divisions of day for effecting on No. of traffic accidents during period $(2012-2016)$ :

\section{- Description Analysis:}

The statistical of data, which obtained from ELSTAT included of traffic accidents No. and divided according to gender drivers who involved in the accidents. In addition, they distributed depending on times of accidents occurrence. The descriptive analysis is showing that there are differences in total No. of traffic accidents according to times of accidents between male and female drivers through period of study (2012-2016) as shown in the statistical Table 5 and Figure 2.

Table 5: Statistical Data of Total No. of Traffic Accidents According to Gender of Drivers through Different Time Divisions of Day during period (2012-2016)

\begin{tabular}{|c|c|c|}
\hline \multirow{2}{*}{ Time Division of Day } & \multicolumn{2}{|c|}{ Gender of Driver } \\
\cline { 2 - 3 } & Male & Female \\
\hline Late night/Dawn (00:00 - 05:00) & 5334 & 729 \\
\hline Morning/Noon (06:00 - 11:00) & 11678 & 2688 \\
\hline Noon/Afternoon (12:00-17:00) & 17272 & 4194 \\
\hline Evening/Night (18:00-23:00) & 13862 & 2832 \\
\hline Total & $\mathbf{4 8 1 4 6}$ & $\mathbf{1 0 4 4 3}$ \\
\hline
\end{tabular}

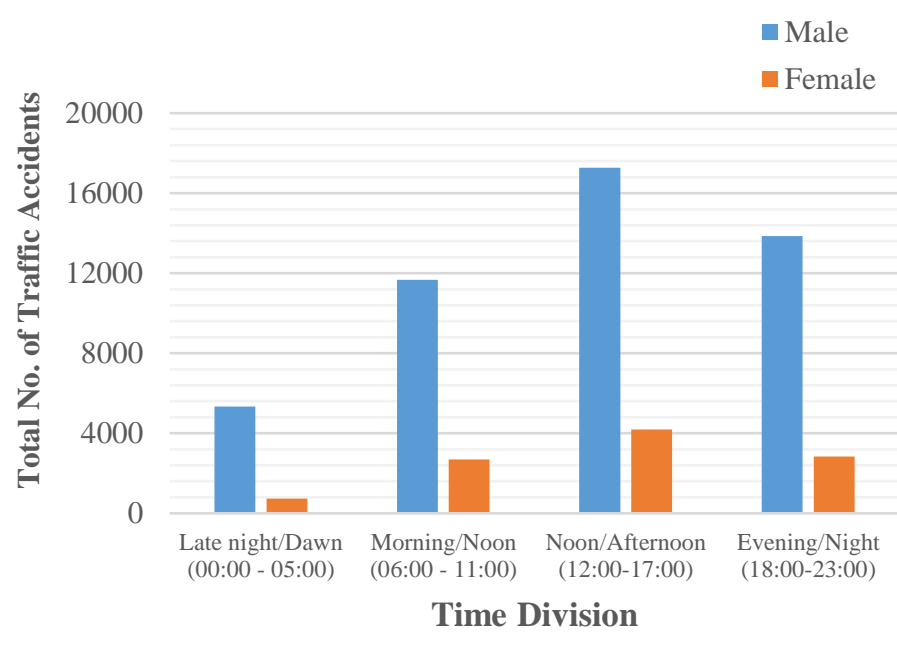

Figure 2: Indication of Total No. of Traffic Accidents

According to Gender of Drivers through Different Time divisions of Day during period (2012-2016)

Depending on the values which shown in Table 5 and Figure 2; we observed that male drivers had the bigger No. of accidents in all time divisions of day comparison to female drivers. In addition, the time division of noon/afternoon that include peak afternoon (12:00-17:00) has the bigger No. of accidents for male and female drivers. After that the values of traffic accidents decreased gradually for time divisions of evening/night (18:0023:00), morning/noon (06:00-11:00) and Late-night/dawn (00:00-05:00 am) consecutively.

This part of analysis included testing the significance of differences between total No. of traffic accidents and gender of drivers through different time divisions of day. In addition, it shown if the traffic accidents affected by gender of drivers and by variety of time divisions depending on data that got during the period $(2012-2016)$. The hypothesis that assumed as the following:

$\mathrm{H}_{0}=$ There is not association between total No. of traffic accidents and the gender of drivers who involved in these accidents through different time divisions of day.

$\mathrm{H}_{1}=$ There is association between total No. of traffic accidents and the gender of drivers who involved in these accidents through different time divisions of day.

For interpretation of the relationship between the dependent variables which included total No. of traffic accidents and independent variables which included gender of drivers and time divisions of day used "Chi-square test" for testing the significance.

Table 6: Chi-Square Test

\begin{tabular}{|c|c|c|c|}
\hline & Value & df & $\begin{array}{c}\text { Asymp. Sig. } \\
\text { (2-sided) }\end{array}$ \\
\hline Pearson Chi-Square & 198.449 & 3 & 0.000 \\
\hline Likelihood Ratio & 211.808 & 3 & 0.000 \\
\hline $\begin{array}{c}\text { Linear-by-Linear } \\
\text { Association }\end{array}$ & 23.783 & 1 & 0.000 \\
\hline N of Valid Cases & 58589 & & \\
\hline
\end{tabular}


Consideration to values of the results in Table 6; the calculated value of chi-square for degree of freedom equals $((\chi 2,3)=$ $198.449)$ and the value of significance $(p=0.000<0.05)$. So that, we reject the hypothesis $\left(\mathrm{H}_{0}\right)$ and accept the hypothesis $\left(\mathrm{H}_{1}\right)$. Then, the differences of total No. of traffic accidents are significant according to gender of drivers and diversity of time divisions through the day at level $(p \leq 0.05)$.

3. Assessment the association between ages' of drivers and time divisions of day for effecting on No. of traffic accidents during period $(2012-2016)$ :

\section{- Description Analysis:}

The statistical of data which got from ELSTAT included of traffic accidents No. and divided according to ages' categories of drivers who involved in the accidents. In addition, they distributed depending on times of accidents occurrence. The descriptive analysis is showing that there are differences in total No. of traffic accidents according to times of accidents between ages' categories of drivers through period of study (2012-2016) as shown in the statistical Table 7 and Figure 3.

Table 7: Statistical Data of Total No. of Traffic Accidents According to Ages of Drivers through Different Time Divisions of Day during period (2012-2016)

\begin{tabular}{|c|c|c|c|c|c|c|}
\hline \multirow{2}{*}{$\begin{array}{c}\text { Time Division } \\
\text { of Day }\end{array}$} & $\mathbf{0 - 1 7}$ & $\mathbf{1 8 - 3 5}$ & $\mathbf{3 6 - 4 9}$ & $\mathbf{5 0 - 6 4}$ & $\mathbf{6 5 +}$ & Unknown \\
\cline { 2 - 7 } & 72 & 3434 & 1391 & 675 & 188 & 303 \\
\hline $\begin{array}{c}\text { Late night/Dawn } \\
(00: 00-05: 00)\end{array}$ & 74 & 4686 & 3994 & 2761 & 2155 & 696 \\
\hline $\begin{array}{c}\text { Morning/Noon } \\
(06: 00-11: 00)\end{array}$ & 188 & 6874 & 6107 & 4432 & 2858 & 1007 \\
\hline $\begin{array}{c}\text { Noon/Afternoon } \\
(12: 00-17: 00)\end{array}$ & 253 & 6516 & 4581 & 2936 & 1562 & 846 \\
\hline $\begin{array}{c}\text { Evening/Night } \\
(18: 00-23: 00)\end{array}$ & $\mathbf{5 8 7}$ & $\mathbf{2 1 5 1 0}$ & $\mathbf{1 6 0 7 3}$ & $\mathbf{1 0 8 0 4}$ & $\mathbf{6 7 6 3}$ & $\mathbf{2 8 5 2}$ \\
\hline Total & & & & & \\
\hline
\end{tabular}

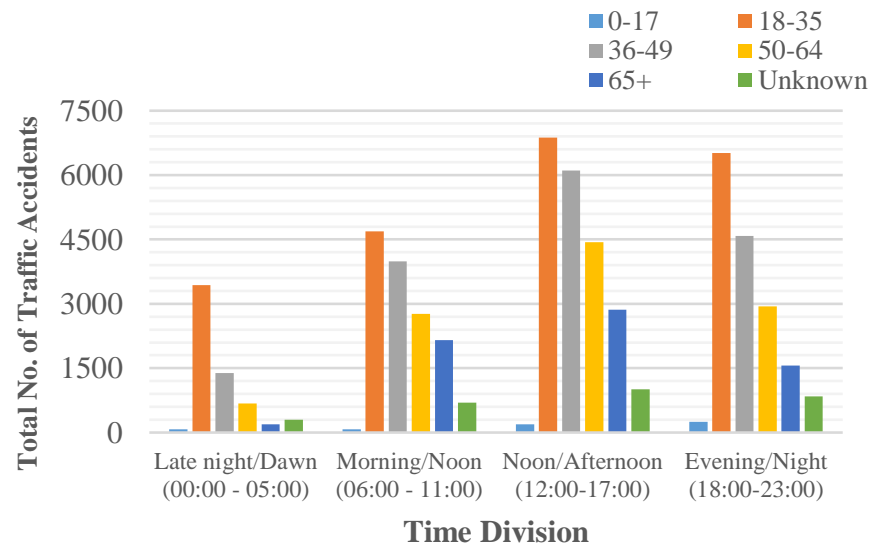

Figure 3: Indication of Total No. of Traffic Accidents According to Ages' Categories of Drivers through Different Time divisions of Day during period (2012-2016)
Depending on the values which shown in Table 7 and Figure 3 ; we noted that age category of young drivers (18-35) had the bigger No. of accidents in all time divisions of day comparison to other ages' categories. In addition, the time division of noon/afternoon that include peak afternoon (12:00-17:00) has the bigger No. of accidents for all ages' categories of drivers. After that the values of traffic accidents decreased gradually for time divisions of evening/night (18:00-23:00), morning/noon (06:00-11:00) and Late-night/dawn (00:00-05:00 am) consecutively.

In addition, the analysis included testing the significance of differences between total No. of traffic accidents and ages' categories of drivers through different time divisions of day. In addition, it shown if the traffic accidents affected by ages of drivers and by variety of time divisions depending on data that got during the period $(2012$ - 2016). The hypothesis that assumed as the following:

$\mathrm{H}_{0}=$ There is not association between total No. of traffic accidents and ages of drivers who involved in these accidents through different time divisions of day.

$\mathrm{H}_{1}=$ There is association between total No. of traffic accidents and ages of drivers who involved in these accidents through different time divisions of day.

For interpretation of the relationship between the dependent variables which included total No. of traffic accidents and independent variables which included ages categories of drivers and time divisions of day used "Chi-square test" for testing the significance.

Table 8: Chi-Square Test

\begin{tabular}{|c|c|c|c|}
\hline & Value & df & $\begin{array}{c}\text { Asymp. Sig. } \\
\text { (2-sided) }\end{array}$ \\
\hline Pearson Chi-Square & 1908.253 & 15 & 0.000 \\
\hline Likelihood Ratio & 1997.426 & 15 & 0.000 \\
\hline $\begin{array}{c}\text { Linear-by-Linear } \\
\text { Association }\end{array}$ & 61.329 & 1 & 0.000 \\
\hline N of Valid Cases & 58589 & & \\
\hline
\end{tabular}

Depending on values of the results in Table 8; the calculated value of chi-square for degree of freedom equals $((\chi 2,15)=$ $1908.253)$ and the value of significance $(p=0.000<0.05)$. So that, we reject the hypothesis $\left(\mathrm{H}_{0}\right)$ and accept the hypothesis $\left(\mathrm{H}_{1}\right)$. Then, the differences of total No. of traffic accidents are significant according to ages of drivers and diversity of time divisions through the day at level $(p \leq 0.05)$.

4. Studying of association level between the variables of gender, ages' categories of drivers and variation of time divisions through day for impaction on differences No. of traffic accidents during period $(2012-2016)$ :

This part of analysis evaluated the impaction of relationships between the variables of gender, ages' categories of drivers and variation of time divisions through day on total No. of traffic accidents. The study testing of the significance between the variables if there are association between them; in addition the hypothesis that assumed as the following: 
$\mathrm{H}_{0}=$ There are not association between gender, ages' categories of drivers and variation of time divisions through day for impaction on differences No. of traffic accidents.

$\mathrm{H}_{1}=$ There are association between gender, ages' categories of drivers and variation of time divisions through day for impaction on differences No. of traffic accidents.

For interpretation of the relationship between the dependent variables which included total No. of traffic accidents and independent variables which included gender, ages' categories of drivers and variation of time divisions used "Univariate Analysis of Variance".

Table 9: Univariate Analysis of Variance Test

\begin{tabular}{|c|c|c|c|c|c|}
\hline Source & $\begin{array}{c}\text { Type III Sum of } \\
\text { Squares }\end{array}$ & df & $\begin{array}{l}\text { Mean } \\
\text { Square }\end{array}$ & $\mathrm{F}$ & Sig. \\
\hline $\begin{array}{c}\text { Corrected } \\
\text { Model }\end{array}$ & 173020276.650 & 47 & 3681282.482 & 9556.799 & 0.000 \\
\hline Intercept & 5288022.707 & 1 & 5288022.707 & 13727.979 & 0.000 \\
\hline Gender & 2028601.442 & 1 & 2028601.442 & 5266.354 & 0.000 \\
\hline Age & 9681921.476 & 5 & 1936384.295 & 5026.953 & 0.000 \\
\hline $\begin{array}{c}\text { Times of } \\
\text { Day }\end{array}$ & 604089.502 & 3 & 201363.167 & 522.749 & 0.000 \\
\hline $\begin{array}{c}\text { Gender * } \\
\text { Age }\end{array}$ & 3833252.571 & 5 & 766650.514 & 1990.264 & 0.000 \\
\hline $\begin{array}{c}\text { Gender * } \\
\text { Times of } \\
\text { Day }\end{array}$ & 185055.782 & 3 & 61685.261 & 160.138 & 0.000 \\
\hline $\begin{array}{c}\text { Age * } \\
\text { Times of } \\
\text { Day }\end{array}$ & 1603341.916 & 15 & 106889.461 & 277.491 & 0.000 \\
\hline $\begin{array}{l}\text { Gender * } \\
\text { Age * } \\
\text { Times of } \\
\text { Day }\end{array}$ & 759652.107 & 15 & 50643.474 & 131.473 & 0.000 \\
\hline Error & 22550015.703 & 58541 & 385.200 & & \\
\hline Total & 837853877.000 & 58589 & & & \\
\hline $\begin{array}{c}\text { Corrected } \\
\text { Total }\end{array}$ & 195570292.353 & 58588 & & & \\
\hline
\end{tabular}

Depending on values which resulted in Table 9; the value of (FGender $*$ Age $*$ Times of Day $=131.473)$ at degree of freedom $(\mathrm{df}=15)$ and the value of significance $(\mathrm{p}=0.00<0.05)$. So that, we reject the hypothesis $\left(\mathrm{H}_{0}\right)$ and accept the hypothesis $\left(\mathrm{H}_{1}\right)$. Then there is association between the dependent variables for impaction on total No. of traffic accidents and there is significant at level $(\mathrm{p} \leq 0.05)$.

\section{Analysis of Model:}

The model Concluded equation which illustration No. of traffic accidents, which are resulting in Greece during variety of time division during the day and considering to some characteristics of drivers that are genders and ages of them. This part of analysis depended on dependent variables which were No. of traffic accidents and independent variables that were age categories and gender of drivers during period (2012 - 2016).

The equation of model resulted by Poisson Regression Model and it considered female of gender variables, (36-49) of age categories variables of drivers and evening/night (18:00-23:00) of time divisions variables as the references in the analysis as showing in the following:

$\log (Y)=\beta_{0}+\beta_{1} X_{1}+\beta_{2} X_{2}+\beta_{3} X_{3}+\ldots \ldots . .+\beta_{n} X_{n}$

$\log$ (No. of Traffic Accidents) $=\beta_{0}+\beta_{1}$ Gender1 (Male) $+\beta_{2}$ Age Category (1) $+\beta_{3}$ Age Category (2) $+\beta_{4}$ Age Category (4) $+\beta_{5}$ Age Category (5) $+\beta_{6}$ Age Category (6) $+\beta_{7}$ (Late-night/dawn) $+\beta_{8}$ (morning/noon) $+\beta_{9}$ (noon/afternoon)

The model included dependent variable of traffic accidents No., probability Distribution of Poisson, link function of Log and $\mathrm{N}=1440$.

Table 10: Omnibus Test ${ }^{\text {a }}$

\begin{tabular}{|c|c|c|}
\hline $\begin{array}{c}\text { Likelihood Ratio Chi- } \\
\text { Square }\end{array}$ & df & Sig. \\
\hline 72712.013 & 9 & 0.000 \\
\hline $\begin{array}{l}\text { Dependent Variable: Traffic Accidents No. } \\
\text { Model: (Intercept), Gender, Age, Time of Day } \\
\text { a. Compares the fitted model against the intercept-only } \\
\text { model. }\end{array}$ \\
\hline
\end{tabular}

The calculated values which are showing in Table 10 of Omnibus Test that included Likelihood Ratio Chi-Square and degree of freedom $(\mathrm{df})$; The value of $\mathrm{p}$ which resulted by the test is significant between the dependent variable of traffic accidents No. and independent variables of genders, ages of drivers and time divisions of day. Whereas $(p=0.000)$ at level of significant $(\mathrm{p} \leq 0.005)$.

Dependent on the values which resulted in Table 11 that included Wald Chi-Square and df; The value of $p$ which resulted by the test is significant all the variables. Whereas $(p=0.000)$ at level of significant $(p \leq 0.005)$. 
Table 11: Tests of Model Effects

\begin{tabular}{|c|c|c|c|}
\hline \multirow{2}{*}{ Source } & \multicolumn{3}{|c|}{ Type III } \\
\cline { 2 - 4 } & Wald Chi-Square & df & Sig. \\
\hline (Intercept) & 96963.472 & 1 & 0.000 \\
\hline Gender & 20044.265 & 1 & 0.000 \\
\hline Age & 21583.362 & 5 & 0.000 \\
\hline Time of Day & 7757.022 & 3 & 0.000 \\
\hline Dependent Variable: Traffic Accidents No. \\
Model: (Intercept), Gender, Age, Time of Day
\end{tabular}

Table 12: Parameter Estimates

\begin{tabular}{|c|c|c|c|c|c|}
\hline \multirow[t]{2}{*}{ Parameter } & \multirow[t]{2}{*}{ B } & \multicolumn{3}{|c|}{ Hypothesis Test } & \multirow[t]{2}{*}{$\operatorname{Exp}(B)$} \\
\hline & & $\begin{array}{c}\text { Wald Chi- } \\
\text { Square }\end{array}$ & df & Sig. & \\
\hline$\left(\mathrm{B}_{0}\right)$ & 3.304 & 59397.504 & 1 & 0.000 & 27.210 \\
\hline [Male] & 1.528 & 20044.265 & 1 & 0.000 & 4.610 \\
\hline [Female] & 0 & . & . & . & 1 \\
\hline [Age (-17)] & $-3.310-$ & 6204.150 & 1 & 0.000 & 0.037 \\
\hline [Age (18-35)] & 0.291 & 781.010 & 1 & 0.000 & 1.338 \\
\hline [Age (Unknown)] & $-1.729-$ & 7242.042 & 1 & 0.000 & 0.177 \\
\hline [Age (50-64)] & $-0.397-$ & 1019.466 & 1 & 0.000 & 0.672 \\
\hline [Age (+65)] & $-0.866-$ & 3567.182 & 1 & 0.000 & 0.421 \\
\hline [Age (36-49)] & 0 & . & . & . & 1 \\
\hline [Late-night/dawn] & $-1.013-$ & 4562.666 & 1 & 0.000 & 0.363 \\
\hline [Morning/noon] & $-0.150-$ & 174.160 & 1 & 0.000 & 0.861 \\
\hline [Noon/afternoon] & 0.251 & 593.617 & 1 & 0.000 & 1.286 \\
\hline [Evening/night] & 0 & . & . & . & 1 \\
\hline (Scale) & 1 & & & & \\
\hline
\end{tabular}

The calculated values that resulted in Table 12 of Parameter Estimates are included values of coefficient (B), Wald ChiSquare, df, significant and EXP (B). The coefficient values are providing the required values and information to predict total No. of traffic accident from independent variables, as well as determine whether independent variables are statistically significantly to the model (by looking at the "Sig." column) at level of significant $(\mathrm{p} \leq 0.005)$.

According to values in Table 12; the equation of Poisson Regression model as the following:

$\log$ (No. of Traffic Accidents) $=3.304+1.528$ (Male) -3.310 Age Category (1) + 0.291 Age Category (2) - 0.397 Age Category (4) - 0.866 Age Category (5) - 1.729 Age Category (6)
- 1.013 (Late-night/dawn) - 0.150 (Morning/noon) + 0.251 (Noon/afternoon)

- The value of (1.528) which resulted indicating for the total traffic accidents No., which resulted by male drivers that in average is bigger than value of total No. of traffic accident which resulted by female drivers.

- The value of (3.310) which resulted indicating that the total No. of traffic accident for drivers who are in age category (1) of (-17), in average is less than the total No. of traffic accidents of the drivers who are in age category (3) of (3649).

- The value of (0.291) which resulted indicating that the total No. of traffic accident for drivers who are in age category (2) of (18-35), in average is bigger than the total No. of traffic accidents of the drivers who are in age category (3) of (36-49).

- The value of (0.397) which resulted indicating that the total No. of traffic accident for drivers who are in age category (4) of (18-35), in average is less than the total No. of traffic accidents of the drivers who are in age category (3) of (3649).

- The value of (0.866) which resulted indicating that the total No. of traffic accident for drivers who are in age category (5) of (18-35), in average is less than the total No. of traffic accidents of the drivers who are in age category (3) of (3649).

- The value of (1.729) which resulted indicating that the total No. of traffic accident for drivers who are in age category (6) of (unknown), in average is less than the total No. of traffic accidents of the drivers who are in age category (3) of (36-49).

- The value of (1.013) which resulted are indicating about No. of traffic accidents which occurred at time division of (Latenight/dawn), in average is less than the value of total traffic accidents No. which occurred at time division of (Evening/night).

- The value of (0.150) which resulted are indicating about No. of traffic accidents which occurred at time division of (Morning/noon), in average is less than the value of total traffic accidents No. which occurred at time division of (Evening/night).

- The value of (0.251) which resulted are indicating about No. of traffic accidents which occurred at time division of (Noon/afternoon), in average is bigger than the value of total traffic accidents No. which occurred at time division of (Evening/night).

\section{CONCLUSIONS}

Depending on the results of study which obtained; the main conclusions and facts that got as the following:

1. There is association between different No. of traffic accidents which involved the drivers and the variation of time divisions through the day. In addition, the differences in time during the day have impacts on No. of accidents which are resulting and it became clear that some time divisions have more No. of accidents comparison to others. 
2. The time division of noon/afternoon that includes the peak of traffic at afternoon (12:00-17:00) considered the critical division for road safety because it has the bigger No. of traffic accidents for all drivers' groups comparison to other divisions of time during the day.

3. The time division of Late-night/dawn (00:00-05:00 am) has the lowest No. of traffic accidents comparison to other divisions of time through the day.

4. There is relationship between genders of drivers who involved in the accidents through variation of time divisions during the day and different No. of traffic accidents.

5 . The diversity of drivers' gender lead to be differences in No. of traffic accidents that are resulting; depending on time different during the day. Whereas, male drivers had the bigger No. of accidents in all time divisions of day comparison to female drivers. In addition, the time division of noon/afternoon that include peak afternoon (12:00-17:00) has more negative effects considering to road safety because it had the bigger No. of accidents for male and female drivers comparison to other divisions.

6. There is association between ages of drivers who involved in the accidents through variation of time divisions during the day and different No. of traffic accidents.

7. Young drivers who have age category of (18-35) consider more negative influencing on road safety because they had the bigger No. of traffic accidents in all divisions of time during the day comparison to other ages' categories. In addition, the time division of noon/afternoon that include peak afternoon (12:0017:00) has the bigger No. of accidents for all ages' categories of drivers.

8. There are relationships between the variables of gender, ages' categories of drivers and variation of time divisions through day for impaction on differences No. of traffic accidents.

9. The behaviors of female drivers during driving of vehicle are better than male drivers at all times of the day, whereas No. of traffic accidents which are resulting from female drivers less than male.

\section{RECOMMENDATION}

Based on the outcomes and conclusions of the study; There are some recommends which are contribution in reduction of traffic accidents during different divisions of time through the day. Some of the recommendations as the following:

1. Motivation the diversity groups of drivers to improve their behaviors through driving of vehicles at different times during the daytime or nighttime.

2. Increasing and permanence the traffic awareness for the drivers and development the means of visual and audio announcements for clarifying to them the positive aspects for achieving of traffic safety on roads.

3. Illustration the risks of the violations of traffic instructions to the drivers and negatives results of traffic accidents that may lead to death, injury or at least causing the damages of vehicles and economic losses.

4. Development the ways of traffic monitoring for drivers by using intelligent systems.

5. Implementation the penalties for deterring the violations of drivers for decreasing the reasons that lead to occurrence of traffic accidents.
6. Urging the drivers to adhere to traffic rules during peak times to avoid the mistakes that contribute to occur the traffic accidents.

7. Applying the required instructions during driving at nighttime, such as using the lighting system of vehicle and ensuring to drive on roads that are qualified to use at night.

\section{ACKNOWLEDGMENT}

We extend our thanks and gratitude the Highway Laboratory at Division of Transportation and Project Management in School of Engineering at Aristotle University of Thessaloniki for introducing all their supports and facilities to conduct the study and publishing through them. In addition, we are very grateful to Hellenic Statistical Authority (ELSTAT) for their cooperation and providing us the statistical data, which are required for preparing the research.

\section{REFERENCES}

[1] World Health Organization (WHO), (2018), "Road Traffic Injuries". Available from internet: <http://www.who.int/newsroom/fact-sheets/detail/road-traffic-injuries>.

[2] D. Massie and K. Campbell, (1993), "Analysis of Accident Rates by Age, Gender, and Time of Day Based on the 1990 Nationwide Personal Transportation Survey", University of Michigan, Transportation Research Institute. 90 p.

[3] M. Sullman, M. Meadows and K. Pajo, (2002), "Aberrant Driving Behaviours Amongst New Zealand Truck Drivers”, Pergamon, Transportation Research 5(3): 217-232.

[4] P. Ulleberg, and T. Rundmo, (2003), "Personality Attitudes and Risk Perception as Predictors of Risky Driving Behaviour Among Young Drivers", Safety Science 41(5): 427-443.

[5] M. Arif, M. Ahmed and S. Rasool, (2015), "Road Traffic Accidents; Autopsy Based Study in Multan", The Professional Medical Journal, 2015;22(5):621-626.

[6] S. Oltedal, T. Rundmo, (2006), "The Effects of Personality and Gender on Risky Driving Behaviour and Accident Involvement", Safety Science 44 (1): 621-628.

[7] S. Plainis, I. Murray and I. Pallikaris, (2006), "Road Traffic Casualties: Understanding the Night-time Death Toll", Injury Prevention, 2006, 12:125-128.

[8] S. Ginpil, R. Attewell, (1994), "A Comparison of Fatal Crashes Involving Male and Female Car Drivers", Federal Office of Road Safety \& INTSTAT Australia pty. Ltd. 48 p.

[9] D. Chang, (2006), "Comparison of Crash Fatalities by Sex and Age Group", Traffic Safety Facts, USA. 6 p.

[10] P. Zador, S. Krawchuk and R. Voas, (2000), "Relative Risk of Fatal and Crash Involvement by BAC, Age and Gender", National Highway Traffic Safety Administration Office of Research and Traffic Records, USA. 31 p.

[11] International Transport Forum and International Traffic Safety Data and Analysis Group (IRTAD), (2017), "Road Safety Annual Report, ITF (2017), OECD Publishing, Paris. 584 p.

[12] D. Clarke, P. Ward, C. Bartle and W. Truman, (2010), "Killer Crashes: Fatal Road Traffic Accidents in the UK", Accident Analysis and Prevention, 42 (2010), 764-770. 